\title{
THE INFLUENCE OF STRIP CROPPING ON THE STATE AND DEGREE OF WEED INFESTATION IN DENT MAIZE (Zea mays L.), COMMON BEAN (Phaseolus vulgaris L.), AND SPRING BARLEY (Hordeum vulgare L.)
}

\author{
Aleksandra Głowacka \\ University of Life Sciences in Lublin, Faculty of Agricultural Sciences in Zamość \\ Szczebrzeska 102, 22-400 Zamość, Poland \\ e-mail: aleksandra.glowacka@up.lublin.pl
}

Received: 02.03.2012

\begin{abstract}
The experiment was conducted in the years 2008-2010 at the Experimental Station of the Faculty of Agricultural Sciences in Zamość, University of Life Sciences in Lublin. The following factors were analysed in the experiment: I. Cultivation method - sole cropping and strip cropping, which consisted in the cultivation of three plants: dent maize, common bean, and spring barley, in adjacent strips with a width of $3.3 \mathrm{~m}$; II. Weed control methods - mechanical and chemical. The subject of the research was weed infestation of the 'Celio' variety of dent maize, the 'Aura' variety of common bean, and the 'Start' variety of spring barley. Weed infestation of the crops was assessed two weeks before harvesting by determining the species composition as well as the number and dry weight of weeds.

The dominant weed species in maize, common bean and spring barley were Echinochloa crus-galli, Chenopodium album and Galinsoga parviflora, constituting from 58\% to $70 \%$ of the total number of weeds. Strip cropping clearly reduced the number of weeds per unit area in all the cultivated species and dry weight of aboveground parts produced by them in common bean and maize crops. The limiting effect of strip cropping on the weed infestation parameters was particularly clear in combination with the mechanical weed control method.
\end{abstract}

Key words: cropping system, weed control, dent maize, common bean, spring barley

\section{INTRODUCTION}

Intercropping has been used for many years in different parts of the world for food and feed production (C a rruthers , 1998). Due to its more efficient use of nutrients, light and water, this system contributes to more stable yields and reduces expenditures necessary for cultivation ( $\mathrm{Zhang}$ and $\mathrm{Li}, 2003$ ).
Strip cropping is a form of intercropping which attempts to reconcile the interests of the farmer and the environment. It involves growing two or more species of plants in strips wide enough to allow independent mechanical cultivation, yet narrow enough for the interaction of ecological factors. Placing the plants in separate strips minimizes competition between them, while a greater diversity of species increases the stability of the agricultural ecosystem (B u r c z y k, 2003). Strip cropping can bring many benefits. It protects the soil from wind and water erosion, reduces mineral leaching, and increases plant yield in comparison with sole cropping (S mith et al. 1991; Ghaffa$\mathrm{rzadeh}$ et al. 1998; Leosing and Francis, 1999; Zhang and Li, 2003; Rogobete and Grozav, 2011). It also reduces competition from pests, diseases, especially those depending on weather conditions, and weeds, so that pesticide use can be restricted ( $\mathrm{L} \mathrm{i} \mathrm{e} \mathrm{b} \mathrm{-}$ $\mathrm{m} \mathrm{an}$ and D y $\mathrm{k}, 1993$ ). In the few studies on strip cropping conducted in Poland, it has been found to reduce the number of weeds in common bean and dent maize and to reduce their biomass in common bean. This beneficial effect of strip cropping was particularly pronunced when used in combination with mechanical weed control (G ł o w a c k a, 2008; G ł o w a c k a , 2010). The effectiveness of strip cropping depends on proper selection of species and even varieties of crops, the widths of the strips, and weather conditions during the growing season. The aim of this study was to assess the influence of cultivation methods (sole cropping and strip cropping) in combination with various methods of weed control (mechanical and chemical) on the state and degree of weed infestation of dent maize, common bean and spring barley. 


\section{MATERIALS AND METHODS}

A field experiment was conducted in the years 2008-2010 at the Experimental Station of the Faculty of Agricultural Sciences in Zamość, University of Life Sciences in Lublin $\left(50^{\circ} 42^{\prime} \mathrm{N}, 23^{\circ} 16^{\prime} \mathrm{E}\right)$, on brown soil which was slightly acidic $(\mathrm{pH} 1 \mathrm{n} \mathrm{KCl}-6.2)$, with an average content of organic matter $\left(19 \mathrm{~g} \times \mathrm{kg}^{-1}\right)$, a high content of available phosphorus and potassium ( $\mathrm{P}$ $185 \mathrm{mg} \times \mathrm{kg}^{-1}$ and $\mathrm{K}-216 \mathrm{mg} \times \mathrm{kg}^{-1}$ ), and average magnesium content $\left(57 \mathrm{mg} \times \mathrm{kg}^{-1}\right)$. The experiment was carried out in a split-plot design in four replications. The subject of the research was weed infestation of the 'Celio' variety of dent maize, the 'Aura' variety of common bean, and the 'Start' variety of spring barley. The following factors were analysed in the experiment:

I. Cropping method: a. sole cropping, in which the size of one plot of each plant was $26.4 \mathrm{~m}^{2}$ for sowing and $22.0 \mathrm{~m}^{2}$ for harvesting; b. Strip cropping, in which three crops - dent maize (Zea mays L.), common bean (Phaseolus vulgaris L.), and spring barley (Hordeum vulgare L.) - were grown side-by-side, each in separate strips $3.3 \mathrm{~m}$ wide. The distance between rows in the adjacent strips was $55 \mathrm{~cm}$ for maize and beans, $35 \mathrm{~cm}$ for beans and barley, and $45 \mathrm{~cm}$ for barley and maize. The size of the plots was $13.2 \mathrm{~m}^{2}$ for sowing and $11 \mathrm{~m}^{2}$ for harvesting.

II. Method of weed control: A - Mechanical: maize - weeding of interrows twice (first in the 5-6 leaf stage - BBCH 15-16 - and again two weeks later); common bean - weeding of interrows twice (first 4-5 weeks after sowing, then 3 weeks later); spring barley - harrowing twice (first at the one-leaf stage - BBCH $10-$ and again at the 5-leaf stage - BBCH 15); B - Chemical: maize - herbicides: a.i. bromoxynil + terbuthylazine at $144 \mathrm{~g} \times \mathrm{ha}^{-1}+400 \mathrm{~g} \times \mathrm{ha}^{-1}$ at the 4-6 leaf stage (BBCH 14/16); common bean - herbicides: a.i. trifluralin before sowing at $810 \mathrm{~g} \times \mathrm{ha}^{-1}+$ bentazon at $1.200 \mathrm{~g} \times \mathrm{ha}^{-1}$ after emergence, when the first pair of trifoliate leaves had unfolded in bean plants (BBCH 13-14) and most of dicotyledonous weeds were at the 4-leaf stage (BBCH 14); spring barley - herbicide: a.i. 4-chloro-2-methylphenoxyacetic acid at $500 \mathrm{~g}$ $\times$ ha $^{-1}$ at the full tillering stage (BBCH 22-23).

Maize was grown in the experiment because it is highly responsive to the border effect. In Poland common bean is grown for food more frequently than any other leguminous plant and south-eastern Poland is a region with particularly favorable conditions for growing it. The third crop, spring barley, was introduced to reduce the negative impact of maize, mainly due to shading, on bean plants grown in adjacent strips.
Agricultural procedures:

Dent maize was grown for silage on a site where the previous crop was spring barley. Mineral fertilization was applied uniformly in the following amounts: $\mathrm{N}-140 ; \mathrm{P}-35$; and $\mathrm{K}-100 \mathrm{~kg} \times \mathrm{ha}^{-1}(\mathrm{~N}$ in the form of ammonium nitrate, $\mathrm{P}$ - triple superphosphate, $\mathrm{K}-$ potassium salt). Phosphorus and potassium fertilization was introduced once before spring pre-sowing treatments, and nitrogen was applied in split applications (half before sowing, and the rest for top dressing at the 4-5 leaf stage - BBCH 14-15). In the subsequent years of the study, maize was sown on $28^{\text {th }}$ April and on $2^{\text {nd }}$ and $5^{\text {th }}$ May. The sowing rate was 110.000 plants per hectare, and the spacing between rows of maize was $65 \mathrm{~cm}$. In sole cropping, 10 rows of maize were planted on the plot, while in strip cropping 5 rows were planted. Tillage was carried out according to the recommendations for maize cultivation. The maize was harvested at the milky dough stage (BBCH 79-83).

Common bean was grown on a site where the previous crop was maize. Mineral fertilization was applied uniformly in the following amounts: $\mathrm{N}-30$; $\mathrm{P}-35$; and $\mathrm{K}-83 \mathrm{~kg} \times \mathrm{ha}^{-1}(\mathrm{~N}$ - ammonium nitrate, $\mathrm{P}$ - triple superphosphate, $\mathrm{K}$ - potassium sulphate). All fertilizers were applied once before sowing. Tilling was carried out using the traditional method in accordance with the agrotechnical recommendations for this plant. In the subsequent years of the study, beans were sown on $28^{\text {th }}$ April and on $2^{\text {nd }}$ and $5^{\text {th }}$ May. The distance between rows was $45 \mathrm{~cm}$ and the density was 350.000 plants per hectare. In sole cropping, 14 rows of beans were planted on the plot, while in strip cropping 7 rows were planted. Before sowing, seeds were mixed with Vitavax 200 FS (a.i. carboxin $200 \mathrm{~g} \times \mathrm{l}^{-1}+$ thiram $\mathrm{g} \times \mathrm{l}^{-1}$ ). Beans were grown for dry seeds and harvested by hand in the third week of August or the first week of September, depending on the year of the study.

Spring barley was grown at a site where the previous crop was common bean. Mineral fertilization was applied uniformly in the following amounts: $\mathrm{N}-90 ; \mathrm{P}-22$; and $\mathrm{K}-83 \mathrm{~kg} \times \mathrm{ha}^{-1}(\mathrm{~N}-$ ammonium nitrate, $\mathrm{P}$ - triple superphosphate, $\mathrm{K}$ - potassium salt). Phosphorus and potassium fertilization were applied once before sowing, while nitrogen was applied in split applications - first $60 \mathrm{~kg} \mathrm{x} \mathrm{ha}^{-1}$ before sowing and the remainder for top dressing at the beginning of stem elongation (BBCH 30-33). In the subsequent years of the study, barley was sown on $12^{\text {th }}, 15^{\text {th }}$ and $19^{\text {th }}$ April at an amount of 350 seeds $\mathrm{m}^{-2}$. All seeds were mixed with the seed dressing Dublet before sowing. Tilling was carried out in accordance with agrotechnical recommendations for barley. Barley was harvested in the first or second ten days of August (BBCH 89).

In each of the crops grown in the experiment, the herbicides were applied with a Pilmet Sano 2 P-030 backpack sprayer. 
Weather conditions during the study period varied (Table 1). Based on the amount of rainfall in each growing season as well as on the criteria and terminology prepared by Kac z or ow s ka (1962), all growing seasons during the study can be considered to be average.

Weed infestation of the crops was assessed two weeks before harvesting by determining the species composition as well as the number and dry weight of weeds. On each plot, two random sample areas were marked off with a $1 \mathrm{~m} \times 0.5 \mathrm{~m}$ frame. Within each frame, individual weed plants were counted and the floristic composition was determined. When the weeds had been extracted and their roots cut off, the plants were dried and weighed to determine the air-dry weight of individual species and the total weight of weeds. Species nomenclature followed M i r e k et al. (2002). The results were analysed statistically using variance analysis. The differences between means were evaluated with Tukey's test. The results were tested at $95 \%$ probability.

Table 1

Rainfall and air temperature in months IV-IX as compared to the long-term means (1971-2005), according to the Meteorological Station in Zamość

\begin{tabular}{|c|c|c|c|c|c|c|c|}
\hline \multicolumn{8}{|c|}{ Rainfall (mm) } \\
\hline Year & IV & $\mathrm{V}$ & VI & VII & VIII & IX & IV-IX \\
\hline 2008 & 71.5 & 74.8 & 48.9 & 104.6 & 69.7 & 80.4 & $449.9 \mathrm{P} *$ \\
\hline 2009 & 15.5 & 102.6 & 124.4 & 24.2 & 48.9 & 34.5 & $350.1 \mathrm{P}$ \\
\hline 2010 & 30.7 & 106.7 & 62.9 & 143.5 & 86.1 & 25.4 & $455.3 \mathrm{P}$ \\
\hline Means for $1971-2005$ & 44.1 & 65.5 & 78.9 & 98.4 & 54.3 & 52.2 & 393.5 \\
\hline \multicolumn{8}{|c|}{ Temperature $\left({ }^{\circ} \mathrm{C}\right)$} \\
\hline 2008 & 10.7 & 15.5 & 19.4 & 20.2 & 20.6 & 19.7 & 3031 \\
\hline 2009 & 11.3 & 13.8 & 20.2 & 20.0 & 20.1 & 16.9 & 3122 \\
\hline 2010 & 11.0 & 15.1 & 18.4 & 21.5 & 20.2 & 16.6 & 3141 \\
\hline Means for $1971-2005$ & 7.9 & 14.1 & 16.8 & 18.4 & 17.8 & 12.9 & 2690 \\
\hline
\end{tabular}

* - assessment of seasons as concerns atmospheric precipitation according to K a c z o r o w s k a (1962): P - average

\section{RESULTS}

\section{Dent maize}

The experimental factors analyzed significantly influenced weed infestation of maize. There were 22 species of weeds in the maize crop, of which 18 were ephemeral and 4 perennial (Table 2). Among the 22 species infesting the maize crop, only 4 were monocots: Echinochloa crus-galli, which was abundant in all combinations, as well as Setaria pumila, Setaria viridis and Elymus repens, which occurred sporadically. The vast majority of the weeds 18 taxa - were dicotyledonous. However, despite the small number of monocot species, they accounted for $40-43 \%$ of the total number of weeds. Species diversity in the dent maize crop was higher in sole cropping than in strip cropping. The method of weed control, by contrast, did not affect the number of weed species inhabiting the maize crop. Irrespective of the experimental factors, Echinochloa crus-galli, Galinsoga parviflora and Chenopodium album were the most frequently occurring species. These dominant species accounted for $67 \%$ of the total number of weeds in strip cropping and $72 \%$ in sole cropping. They also produced a large amount of dry matter, especially where mechanical weed control was used (Fig. 1). Among these species, the most numerous were Polygonum nodosum, Setaria pumila, Galinsoga ciliata, Sonchus oleraceus and Cirsium arvense. Other species occurred rarely or sporadically (Table 2 ).

In the maize grown in strips with common bean and spring barley, the total number of weeds per unit area was significantly lower - by $27 \%$ - than in sole cropping. Like the number of weeds, the weight of their above-ground parts was significantly lower in strip cropping. The weed control methods also strongly differentiated the weed density. On average for the whole experiment, the number of weeds was 2.7 times lower where the chemical method was used than in the case of mechanical weed control alone. Chemical weed control strongly reduced the occurrence of Echinochloa crus-galli, Chenopodium album and Galinsoga parviflora. The effect of weed control methods as regards the weight of weeds was also very pronounced 
in each year of the study. On average, the dry weight of weeds at the sites with mechanical weed control was three times higher than at the sites where herbicides were used. Strip cropping with mechanical weed control decreased the number of weeds by $32.5 \%$ and their weight by $41 \%$ compared to sole cropping. At the sites where herbicides were used, these values were $17.6 \%$ and $16.3 \%$ for the number and weight of weeds, respectively (Table 6).

\section{Common bean}

Irrespective of the experimental factors, the most frequently occurring species in the common bean crops were Echinochloa crus-galli, Galinsoga parviflora and Chenopodium album. These three dominant segetal species accounted for $55 \%$ to $85 \%$ of the total number of weeds. After these, the most numerous were Capsella bursa-pastoris, Galium aparine, Stellaria media, Polygonum nodosum and Setaria pumila. Other species occurred rarely or sporadically. Overall, there were 24 weed species in the common bean crop, including 4 perennial and 20 ephemeral species. Among the 24 taxa identified, only three were monocots. However, their share in the total number of weeds was $20 \%$ and $50.5 \%$ in strip cropping and $46.1 \%$ and $58.8 \%$ in sole cropping for mechanical and chemical weed control, respectively. The method of cultivation had no effect on the species diversity of weeds in the common bean crop. In the case of chemical weed control, 20 species were noted, compared with only 14 where the mechanical method was used (Table 3). In each year of the experiment and on average for all study years, strip cropping both led to the occurrence of fewer weeds, by an average of $26 \%$, and reduced their above-ground dry weight, by an average of $33 \%$ compared to sole cropping (Table 7). Worth noting is the observed trend towards greater differences between the cropping methods at the sites with mechanical weed control. At these sites, strip cropping reduced the number of weeds by $32 \%$ and their above-ground dry weight by $42 \%$ compared to sole cropping, while at the sites with chemical weed control the differences were only $14 \%$ and $13 \%$ for the number and biomass of weeds, respectively. The differences between the weed control methods were significant, but not so great as might be expected, especially as regards the number of weeds. On average, the chemical method of weed control decreased the number of weeds by $33 \%$ and their dry weight by $46 \%$ as compared to mechanical weed control (Table 7). The use of herbicides strongly reduced the number of Echinochloa crus-galli, and while it did not significantly affect the numbers of other species, it clearly reduced the biomass produced by Echinochloa crus-galli and Chenopodium album (Fig. 2).

\section{Spring barley}

There were 31 species of weeds identified in the spring barley crop, of which 27 were ephemeral and 4 perennial. Echinochloa crus-galli, Galinsoga parviflora and Chenopodium album were the most frequently occurring species. Their share in the total number of weeds per unit area was $78.6 \%$ and $46.1 \%$ in sole cropping and $77.7 \%$ and $27.6 \%$ in strip cropping for mechanical and chemical weed control, respectively. These taxa also produced a large amount of dry matter, especially at the sites with mechanical weed control (Fig. 3). The next most numerous species were Capsella bursa-pastoris, Galium aparine, Stelaria media, Setaria pumila and Polygonum nodosum. Six of the weed species infesting the barley crop were monocots which accounted for $35 \%$ to $54 \%$ of the total number of weeds in the spring barley crop. Barley grown in sole cropping was infested by 28 segetal species, while 23 were noted in the case of strip cropping (Table 4). There were 27 species noted on the sites where mechanical weed control was used, while significantly fewer - 22 species - were recorded where the herbicide was used. In each year of the study and on average for the experiment, strip cropping significantly reduced the number of weeds in the spring barley crop - by $21 \%$ in comparison with sole cropping. The effect of strip cropping on the above-ground dry matter produced by the weeds varied in different growing seasons, while on average for the entire experiment no significant differences were noted between cultivation methods (Table 8). The use of herbicides for weed control significantly reduced the number of weeds, by an average of $64.4 \%$ compared to mechanical weed control. It greatly reduced the number and biomass of Echinochloa crus-galli and Galinsoga parviflora, and completely eliminated Chenopodium album from weed infestation (Fig. 3). Moreover, the dry weight of weeds at the sites with chemical weed control was significantly lower (47\%). The analysis of the interaction between methods of cultivation and weed control shows that the effect of strip cropping on reducing infestation rates was evident only in combination with mechanical weed control, which is also confirmed by the statistical analysis (Table 8). 
Table 2

Species composition and number of weeds per $1 \mathrm{~m}^{2}$ of a maize crop before harvest depending on the cropping system (mean for 2008-2010)

\begin{tabular}{|c|c|c|c|c|c|c|}
\hline \multirow{2}{*}{ Species composition } & \multicolumn{3}{|c|}{ Sole cropping } & \multicolumn{3}{|c|}{ Strip cropping } \\
\hline & A & B & mean & A & B & mean \\
\hline \multicolumn{7}{|c|}{ Short lived } \\
\hline Echinochloa crus-galli (L) P. Beauv & 20.2 & 7.7 & 14.0 & 14.8 & 5.8 & 10.3 \\
\hline Galinsoga parviflora Cav. & 9.7 & 2.7 & 6,2 & 4.4 & 1.3 & 3.4 \\
\hline Chenopodium album $\mathrm{L}$ & 14.8 & 1.4 & 8,1 & 9.4 & 2.3 & 5.9 \\
\hline Capsella bursa-pastoris (L.) Medik. & 0.2 & - & 0.1 & - & - & - \\
\hline Galium aparine $\mathrm{L}$. & 0.6 & 0.8 & 0.7 & - & 0.7 & 0.4 \\
\hline Stellaria media L. Vill & 0.2 & 0.2 & 0.2 & 0.2 & - & 0.1 \\
\hline Polygonum lapathifolium L. subsp. lapathifolium & 1.8 & 0.8 & 1.3 & 1.3 & 0.7 & 1.0 \\
\hline Setaria pumila (Poir) Roem. \& Schult & 1.2 & 0.9 & 1.1 & 1.4 & 0.6 & 1.0 \\
\hline Melandrium album (Mill.) Gracke & 0.5 & 0.2 & 0.4 & 0.3 & - & 0.2 \\
\hline Amaranthus retroflexus $\mathrm{L}$. & 0.2 & - & 0.1 & - & - & - \\
\hline Veronica persica Poir. & 0.9 & 0.2 & 0.6 & 0.2 & 0.7 & 0.5 \\
\hline Polygonum convolvulus L. & 0.2 & - & 0.1 & - & 0.5 & 0.3 \\
\hline Veronica arvensis L. & - & 0.7 & 0.4 & - & 0.5 & 0.3 \\
\hline Viola arvensis Murray & 0.2 & 0.2 & 0.2 & - & - & - \\
\hline Setaria viridis (L.) P. Bauer. & 0.2 & - & 0.1 & - & - & - \\
\hline Galinsoga ciliata $\mathrm{L}$. & 1.5 & 0.5 & 1.0 & 1.3 & 0.8 & 1.1 \\
\hline Sonchus oleraceus L. & 0.4 & 1.3 & 1.1 & 0.5 & 0.4 & 0.5 \\
\hline Thlaspi arvense L. & - & - & - & 0.2 & - & 0.1 \\
\hline Total of short-lived species & 52.8 & 17.6 & 35.2 & 34.0 & 14.3 & 24.2 \\
\hline \multicolumn{7}{|c|}{ Perennial } \\
\hline Plantago maior (L.) S. Str. & - & - & - & - & 0.3 & 0.2 \\
\hline Equisetum arvense $\mathrm{L}$. & 0.8 & 0.2 & 0.5 & 1.1 & - & 0.6 \\
\hline Cirsium arvense (L.) Scop. & 0.5 & 0.6 & 0.5 & 1.9 & 1.0 & 1.4 \\
\hline Elymus repens (L.) Gould & 0.5 & - & 0.3 & - & - & - \\
\hline Number of perennial species & 1.8 & 0.8 & 1.3 & 3.0 & 1.3 & 2.1 \\
\hline
\end{tabular}

Weed control: A - mechanical, B - chemical 
Table 3

Species composition and number of weeds per $1 \mathrm{~m}^{2}$ of a common bean crop before harvest, depending on the cropping system (mean for 2008-2010)

\begin{tabular}{|c|c|c|c|c|c|c|}
\hline \multirow{2}{*}{ Species composition } & \multicolumn{3}{|c|}{ Sole cropping } & \multicolumn{3}{|c|}{ Strip cropping } \\
\hline & $A^{*}$ & $\mathrm{~B}$ & Mean & A & $\mathrm{B}$ & Mean \\
\hline \multicolumn{7}{|c|}{ Short lived } \\
\hline Echinochloa crus-galli (L) P. Beauv & 41.6 & 15.7 & 34.2 & 23.8 & 7.0 & 16.4 \\
\hline Galinsoga parviflora Cav. & 14.1 & 12.4 & 13.3 & 5.4 & 8.4 & 6.9 \\
\hline Chenopodium album $\mathrm{L}$ & 6.8 & 3.4 & 6.1 & 6.1 & 4.7 & 7.9 \\
\hline Capsella bursa-pastoris (L.) Medik. & 2.3 & 4.1 & 3.2 & 3.3 & 7.7 & 5.5 \\
\hline Galium aparine $\mathrm{L}$. & 1.3 & 2.7 & 2.0 & 1.4 & 1.6 & 1.5 \\
\hline Stellaria media (L.) Vill. & 1.0 & 0.7 & 0.9 & 0.7 & 0.6 & 0.7 \\
\hline Polygonum lapathifolium L. subsp. lapathifolium & 0.7 & 0.3 & 0.5 & 0.3 & 1.1 & 0.7 \\
\hline Setaria pumila (Poir) Roem. \& Schult & 1.4 & 1.0 & 1.2 & 0.3 & 0.4 & 0.4 \\
\hline Melandrium album (Mill.) Gracke & 1.4 & - & 0.7 & - & - & - \\
\hline Thlaspi arvense $\mathrm{L}$ & - & 3.7 & 1.9 & - & 3.4 & 1.7 \\
\hline Lapsana communis L. & - & 0.7 & 0.4 & - & - & - \\
\hline Polygonum convolvulus L. & - & - & - & - & 0.3 & 0.2 \\
\hline Polygonum aviculare L. & 0.3 & 0.3 & 0.3 & - & - & - \\
\hline Vicia hirsuta (L.) Gray., & - & 0.7 & 0.4 & - & 0.7 & 0.4 \\
\hline Matricaria maritima subsp. inodora (L.) Dostal & - & 0.4 & 0.2 & & 0.3 & 0.2 \\
\hline Geranium pusillum L. & - & - & - & - & 0.4 & 0.2 \\
\hline Veronica arvensis L. & - & - & - & - & 0.7 & 0.4 \\
\hline Gnaphalium uliginosum L. & - & - & - & - & 0.3 & 0.2 \\
\hline Anagallis arvensis L. & - & 0.8 & 0.4 & - & - & - \\
\hline Viola arvensis Murray & - & 0.3 & 0.2 & - & - & - \\
\hline Total of short-lived species & 70.9 & 44.2 & 57.6 & 42.0 & 37.6 & 43.3 \\
\hline \multicolumn{7}{|c|}{ Perennial } \\
\hline Taraxacum officinale Web. & 0.3 & 0.8 & 0,6 & - & - & - \\
\hline Equisetum arvense L. & - & 0.3 & 0,2 & 4.3 & - & 2.2 \\
\hline Cirsium arvense $\mathrm{L}$. & 2.0 & 0.3 & 0,3 & 1.4 & 4.0 & 2.7 \\
\hline Agropyron repens $\mathrm{L}$. & - & 0.4 & 0,2 & - & 0.4 & 0.2 \\
\hline Total of perennial species & 2.3 & 1.8 & 2,1 & 5.7 & 4.4 & 5.1 \\
\hline
\end{tabular}

*Weed control: A - mechanical, B - chemical 
Table 4

Species composition and number of weeds per $1 \mathrm{~m}^{2}$ of a spring barley crop before harvest, depending on the cropping system (mean for 2008-2010)

\begin{tabular}{|c|c|c|c|c|c|c|}
\hline \multirow{2}{*}{ Species composition } & \multicolumn{3}{|c|}{ Sole cropping } & \multicolumn{3}{|c|}{ Strip cropping } \\
\hline & A & B & mean & A & B & mean \\
\hline \multicolumn{7}{|c|}{ Short lived } \\
\hline Echinochloa crus-galli (L) P. Beauv & 28.7 & 8.3 & 19.3 & 18.7 & 6.6 & 12.7 \\
\hline Galinsoga parviflora Cav. & 18.8 & 3.5 & 11.2 & 16.6 & 2.7 & 9.7 \\
\hline Chenopodium album $\mathrm{L}$ & 26.4 & - & 8.2 & 13.1 & 0.3 & 6.7 \\
\hline Capsella bursa-pastoris (L.) Medik. & 0.4 & 0.5 & 0.5 & 0.6 & - & 0.3 \\
\hline Galium aparine $\mathrm{L}$. & 2.3 & 2.6 & 2.5 & 1.8 & 3.8 & 2.8 \\
\hline Stellaria media (L.) Vill & 0.9 & 0.2 & 0.6 & 1.1 & 0.9 & 1.0 \\
\hline Polygonum lapathifolium L. subsp. lapathifolium & 4.9 & 0.9 & 2.9 & 3.5 & - & 1.8 \\
\hline Setaria pumila (Poir) Roem. \& Schult & 7.3 & 1.6 & 4.5 & 5.8 & 8.1 & 6.9 \\
\hline Melandrium album (Mill.) Gracke & 0.7 & 1.6 & 1.2 & 0.7 & - & 0.4 \\
\hline Thlaspi arvense $\mathrm{L}$ & - & - & - & 0.3 & - & 0.2 \\
\hline Conyza canadensis $\mathrm{L}$. & - & 0.2 & 0.1 & - & - & - \\
\hline Polygonum convolvulus L. & 1.6 & 0.2 & 0.9 & 0.2 & 1.8 & 1.0 \\
\hline Avena fatua $\mathrm{L}$. & 0.2 & - & 0.1 & 0.4 & - & 0.2 \\
\hline Vicia hirsuta L. & 0.7 & - & 0.4 & 0.7 & 0.3 & 0.5 \\
\hline Matricaria maritima subsp. inodora (L.) Dostal & - & - & - & 0.3 & - & 0.2 \\
\hline Geranium pusillum L. & 1.6 & 0.7 & 1.2 & - & - & - \\
\hline Veronica arvensis L. & 0.5 & 1.1 & 0.8 & 0.7 & 1.1 & 0,9 \\
\hline Gnaphalium uliginosum L. & 0.7 & - & 0.4 & - & - & - \\
\hline Apera spica-venti $\mathrm{L}$. & 0.2 & - & 0.1 & - & - & - \\
\hline Viola arvensis Murray & - & 0.3 & 0.2 & 0.6 & 0.9 & 0.8 \\
\hline Galeopsis tetrahit L. & 0.2 & - & 0.1 & - & - & - \\
\hline Papaver rhoeas L. & 0.2 & - & 0.1 & - & - & - \\
\hline Setaria viridis (L.) P. Bauer. & - & 0.5 & 0.3 & - & 0.4 & 0.2 \\
\hline Lamium purpureum $\mathrm{L}$. & - & - & - & - & 0.9 & 0.5 \\
\hline Sonchus asper (L.) Hill. & 0.2 & - & 0.1 & - & - & - \\
\hline Galinsoga ciliata $\mathrm{L}$. & - & 0.3 & 0.2 & - & - & - \\
\hline Myosotis arvensis L. & 0.3 & - & 0.2 & - & 0.2 & 0.1 \\
\hline Total of short-lived species & 96.6 & 21.6 & 59.1 & 65.1 & 28.0 & 46.6 \\
\hline \multicolumn{7}{|c|}{ Perennial } \\
\hline Plantago maior (L.) S. Str. & 1.3 & - & 0.7 & 0,2 & - & 0.1 \\
\hline Equisetum arvense L. & 0.3 & 1.1 & 0.7 & 0,3 & 3,3 & 1.3 \\
\hline Cirsium arvense (L.) Scop. & 2.0 & 2.9 & 2.5 & 2,9 & 2,0 & 2.5 \\
\hline Elymus repens (L.) Gould & - & - & - & 2,4 & 0,4 & 1.4 \\
\hline Total of perennial species & 3.6 & 4.0 & 3.8 & 5.8 & 5.7 & 5.8 \\
\hline
\end{tabular}


Table 5

Species composition and number of weeds per $1 \mathrm{~m}^{2}$ of tested plants before harvest, average for the weed control method (mean for 2008-2010)

\begin{tabular}{|c|c|c|c|c|c|c|}
\hline \multirow{2}{*}{ Species composition } & \multicolumn{2}{|c|}{ Common bean } & \multicolumn{2}{|c|}{ Maize } & \multicolumn{2}{|c|}{ Spring barley } \\
\hline & $A^{*}$ & $\mathrm{~B}$ & A & $\mathrm{B}$ & A & B \\
\hline \multicolumn{7}{|c|}{ Short-lived } \\
\hline Echinochloa crus-galli (L) P. Beauv & 32.7 & 11.4 & 17.5 & 6.8 & 23.7 & 7.5 \\
\hline Galinsoga parviflora Cav. & 9.8 & 10.4 & 7.1 & 2.0 & 17.8 & 3.1 \\
\hline Chenopodium album $\mathrm{L}$ & 6.5 & 4.1 & 12.1 & 1.9 & 19.8 & 0.2 \\
\hline Capsella bursa-pastoris (L.) Medik. & 2.8 & 5.9 & 0.1 & - & 0.5 & 0.3 \\
\hline Galium aparine $\mathrm{L}$. & 1.4 & 2.2 & 0.3 & 0.8 & 2.1 & 3.2 \\
\hline Stellaria media (L.) Vill & 0.9 & 0.7 & 0.2 & 0.1 & 1.0 & 0.6 \\
\hline Polygonum lapathifolium L. subsp. lapathifolium & 0.5 & 0.7 & 1.6 & 0.8 & 4.2 & 0.5 \\
\hline Setaria pumila (Poir) Roem. \& Schult & 0.9 & 0.7 & 1.3 & 0.8 & 6.6 & 4.9 \\
\hline Melandrium album (Mill.) Gracke & 0.7 & - & 0.4 & 0.1 & 0.7 & 0.8 \\
\hline Thlaspi arvense $\mathrm{L}$ & - & 3.6 & - & 0.1 & 0.2 & - \\
\hline Lapsana communis L. & 0.4 & - & - & - & - & - \\
\hline Conyza canadensis $\mathrm{L}$. & - & - & - & - & - & 0.1 \\
\hline Polygonum convolvulus L. & - & 0.2 & 0.1 & 0.3 & 0.9 & 1.0 \\
\hline Polygonum aviculare L. & & & - & - & & \\
\hline Avena fatua $\mathrm{L}$. & - & - & - & - & 0.3 & - \\
\hline Vicia hirsuta $\mathrm{L}$. & - & 0.7 & - & - & 0.7 & 0.4 \\
\hline Matricaria maritime subsp. inodora (L.) Dostal & - & 0.4 & - & - & 0.2 & - \\
\hline Geranium pusillum L. & - & 0.2 & & & 0.8 & 0.3 \\
\hline Veronica arvensis $\mathrm{L}$. & - & 0.4 & - & 0.6 & 0.6 & 1.1 \\
\hline Gnaphalium uliginosum L. & - & 0.2 & - & - & 0.4 & - \\
\hline Apera spica-venti $\mathrm{L}$. & - & - & - & - & 0.1 & - \\
\hline Viola arvensis Murray & - & 0.2 & 0.1 & 0.1 & 0.3 & 0.6 \\
\hline Anagallis arvensis $\mathrm{L}$ & 0.8 & - & - & - & - & - \\
\hline Galeopsis tetrahit L. & - & - & - & - & 0.1 & - \\
\hline Papaver rhoeas $\mathrm{L}$. & - & - & - & - & 0.1 & - \\
\hline Setaria viridis (L.) P. Bauer. & - & - & 0.1 & - & - & 0.5 \\
\hline Lamium purpureum $\mathrm{L}$. & - & - & - & - & - & 0.5 \\
\hline Sonchus asper (L.) Hill. & - & - & - & - & 0.1 & - \\
\hline Galinsoga ciliata $\mathrm{L}$. & - & - & 1.4 & 0.7 & - & 0.2 \\
\hline Myosotis arvensis L. & - & - & - & - & 0.2 & 0.1 \\
\hline Veronica persica Poir. & - & - & 0.6 & 0.5 & - & - \\
\hline Sonchus oleraceus L. & - & - & 0.5 & 0.9 & - & - \\
\hline Amaranthus retroflexus L. & - & - & 0.1 & - & - & - \\
\hline Total of short-lived species & 57.4 & 37.7 & 43.3 & 16.0 & 78.9 & 24.9 \\
\hline \multicolumn{7}{|c|}{ Perennial } \\
\hline Plantago maior (L.) S. Str. & 0.2 & 0.4 & - & 0.2 & 0.8 & - \\
\hline Equisetum arvense $\mathrm{L}$. & 2.2 & 0.2 & 1.0 & 0.1 & 0.3 & 2.2 \\
\hline Cirsium arvense (L.) Scop. & 1.7 & 2.2 & 1.2 & 0.8 & 2.5 & 2.5 \\
\hline Elymus repens (L.) Gould & - & 0.4 & 0.3 & - & 1.2 & 0.2 \\
\hline Total of perennial species & 4.1 & 3.2 & 2.5 & 1.1 & 4.8 & 4.9 \\
\hline
\end{tabular}

Weed control: A - mechanical, B - chemical 
Table 6

Weed density and air-dry weight of weeds in the maize crop

\begin{tabular}{|c|c|c|c|c|c|c|c|c|c|}
\hline \multirow{3}{*}{$\begin{array}{l}\text { I. Method of } \\
\text { cultivation }\end{array}$} & \multirow{3}{*}{$\begin{array}{l}\text { II. Weed } \\
\text { control }\end{array}$} & \multicolumn{4}{|c|}{ Weed density (per $1 \mathrm{~m}^{2}$ ) } & \multicolumn{4}{|c|}{ Air-dry weight $\left(\mathrm{g} \times \mathrm{m}^{-2}\right)$} \\
\hline & & \multicolumn{3}{|c|}{ Year } & \multirow{2}{*}{ Average } & \multicolumn{3}{|c|}{ Year } & \multirow{2}{*}{ Average } \\
\hline & & 2008 & 2009 & 2010 & & 2008 & 2009 & 2010 & \\
\hline \multirow{2}{*}{ Sole cropping } & $A^{*}$ & 32.6 & 62.1 & 69.4 & 54.7 & 256.2 & 198.7 & 180.9 & 210.7 \\
\hline & $\mathrm{B}$ & 19.7 & 18.1 & 18.8 & 18.8 & 59.8 & 75.3 & 46.4 & 60.1 \\
\hline \multirow{2}{*}{ Strip cropping } & A & 19.6 & 56.9 & 34.3 & 36.9 & 95.0 & 126.9 & 150.3 & 124.1 \\
\hline & B & 12.7 & 14.9 & 18.6 & 15.4 & 42.6 & 61.3 & 46.9 & 50.3 \\
\hline \multicolumn{2}{|c|}{$L S D(=0.05)$ for $\mathrm{I} \times \mathrm{II}$} & 1.70 & n.s. & 8.29 & 3.01 & 17.49 & 4.59 & 3.89 & 8.38 \\
\hline \multicolumn{10}{|c|}{ Average for factors } \\
\hline Sole cropping & - & 26.2 & 40.1 & 44.0 & 36.7 & 155.6 & 137.0 & 113.7 & 135.4 \\
\hline Strip cropping & - & 16.2 & 35.9 & 26.5 & 26.2 & 68.8 & 94.1 & 98.6 & 87.2 \\
\hline \multirow[t]{3}{*}{$\operatorname{LSD}(=0.05)$} & & 1.56 & 1.76 & 7.62 & 2.77 & 16.09 & 4.22 & 3.58 & 7.71 \\
\hline & A & 26.1 & 59.5 & 51.9 & 45.8 & 173.8 & 162.8 & 165.6 & 167.4 \\
\hline & B & 16.2 & 16.5 & 18.6 & $` 17.1$ & 50.6 & 68.3 & 46.9 & 55.2 \\
\hline \multicolumn{2}{|c|}{$\operatorname{LSD}(=0.05)$ for II } & 1.20 & 1.35 & 5.86 & 2.13 & 12.37 & 3.25 & 2.75 & 5.93 \\
\hline
\end{tabular}

Weed control: A - mechanical, B - chemical

Table 7

Weed density and air-dry weight of weeds in the common bean crop

\begin{tabular}{|c|c|c|c|c|c|c|c|c|c|}
\hline \multirow{3}{*}{$\begin{array}{l}\text { I. Method of } \\
\text { cultivation }\end{array}$} & \multirow{3}{*}{$\begin{array}{l}\text { II. Weed } \\
\text { control }\end{array}$} & \multicolumn{4}{|c|}{ Weed density (per $1 \mathrm{~m}^{2}$ ) } & \multicolumn{4}{|c|}{ Air-dry weight $\left(\mathrm{g} \times \mathrm{m}^{-2}\right)$} \\
\hline & & \multicolumn{3}{|c|}{ Year } & \multirow{2}{*}{ Average } & \multicolumn{3}{|c|}{ Year } & \multirow{2}{*}{ Average } \\
\hline & & 2008 & 2009 & 2010 & & 2008 & 2009 & 2010 & \\
\hline \multirow{2}{*}{ Sole cropping } & $A^{*}$ & 35.9 & 109.8 & 73.2 & 73.0 & 333.1 & 244.3 & 299.6 & 292.3 \\
\hline & $\mathrm{B}$ & 17.9 & 74.6 & 46.0 & 46.2 & 155.6 & 117.5 & 124.1 & 131.4 \\
\hline \multirow{2}{*}{ Strip cropping } & A & 26.5 & 74.5 & 47.7 & 49.6 & 151.6 & 185.7 & 169.8 & 169.0 \\
\hline & $\mathrm{B}$ & 16.9 & 59.8 & 42.0 & 39.6 & 95.1 & 131.6 & 115.6 & 114.0 \\
\hline \multicolumn{2}{|c|}{$\operatorname{LSD}(=0.05)$ for I $\mathrm{x}$ II } & n.s. & 1.71 & 3.80 & 1.83 & 21.75 & 1.17 & 3.67 & 7.89 \\
\hline \multicolumn{10}{|c|}{ Average for factors } \\
\hline Sole cropping & - & 26.8 & 92.2 & 60.6 & 59.9 & 244.4 & 180.9 & 211.9 & 212.4 \\
\hline Strip cropping & - & 21.7 & 67.2 & 44.9 & 44.6 & 123.4 & 158.7 & 142.7 & 141.6 \\
\hline \multicolumn{2}{|c|}{$L S D(=0.05)$ for I } & 2.2 & 1.57 & 3.49 & 1.68 & 20.00 & 10.8 & 3.38 & 7.26 \\
\hline- & A & 31.2 & 92.2 & 60.5 & 61.3 & 242.4 & 215.0 & 234.7 & 230.7 \\
\hline- & $\mathrm{B}$ & 17.4 & 65.2 & 40.0 & 40.9 & 125.4 & 124.6 & 119.8 & 123.2 \\
\hline \multicolumn{2}{|c|}{$\operatorname{LSD}(=0.05)$ for II } & 1.69 & 1.21 & 2.69 & 1.29 & 15.38 & 0.83 & 2.60 & 5.58 \\
\hline
\end{tabular}

Weed control: A - mechanical, B - chemical 
Table 8

Weed density and air-dry weight of weeds in the spring barley crop

\begin{tabular}{|c|c|c|c|c|c|c|c|c|c|}
\hline \multirow{3}{*}{$\begin{array}{l}\text { I. Method of } \\
\text { cultivation }\end{array}$} & \multirow{3}{*}{$\begin{array}{l}\text { II. Weed } \\
\text { control }\end{array}$} & \multicolumn{4}{|c|}{ Weed density (per $1 \mathrm{~m}^{2}$ ) } & \multicolumn{4}{|c|}{ Air-dry weight $\left(\mathrm{g} \times \mathrm{m}^{-2}\right)$} \\
\hline & & \multicolumn{3}{|c|}{ Year } & \multirow{2}{*}{ Average } & \multicolumn{3}{|c|}{ Year } & \multirow{2}{*}{ Average } \\
\hline & & 2008 & 2009 & 2010 & & 2008 & 2009 & 2010 & \\
\hline \multirow{2}{*}{ Sole cropping } & $A^{*}$ & 57.6 & 140.0 & 101.6 & 99.7 & 34.8 & 40.7 & 207.6 & 95.2 \\
\hline & B & 19.3 & 21.4 & 39.8 & 26.8 & 9.2 & 8.6 & 110.0 & 42.6 \\
\hline \multirow{2}{*}{ Strip cropping } & $\mathrm{A}$ & 19.7 & 82.1 & 101.4 & 67.7 & 18.5 & 29.9 & 195.6 & 81.3 \\
\hline & $\mathrm{B}$ & 16.5 & 13.7 & 67.9 & 32.7 & 6.6 & 10.0 & 137.8 & 51.5 \\
\hline \multicolumn{2}{|c|}{$\operatorname{LSD}(=0.05)$ for I $\mathrm{x}$ II } & 2.07 & 7.58 & 6.45 & 2.04 & 4.36 & 2.29 & 10.05 & 4.51 \\
\hline \multicolumn{10}{|c|}{ Average for factors } \\
\hline Sole cropping & - & 38.5 & 80.7 & 70.7 & 63.3 & 22.0 & 24.7 & 158.8 & 68.9 \\
\hline Strip cropping & - & 18.1 & 47.9 & 84.7 & 50.2 & 12.6 & 20.0 & 166.7 & 66.4 \\
\hline \multicolumn{2}{|c|}{$\operatorname{LSD}(=0.05)$ for $\mathrm{I}$} & 1.90 & 6.97 & 5.95 & 2.65 & 4.01 & 2.10 & n.s. & n.s. \\
\hline- & $\mathrm{A}$ & 38.6 & 111.1 & 101.5 & 83.7 & 26.7 & 35.3 & 201.6 & 88.2 \\
\hline- & $\mathrm{B}$ & 17.9 & 17.6 & 53.9 & 29.8 & 7.9 & 9.3 & 123.9 & 47.0 \\
\hline $\operatorname{LSD}(=0.05)$ & & 1.46 & 5.36 & 4.57 & 2.88 & 3.08 & 1.62 & 7.11 & 3.19 \\
\hline
\end{tabular}

Weed control: A - mechanical, B - chemical

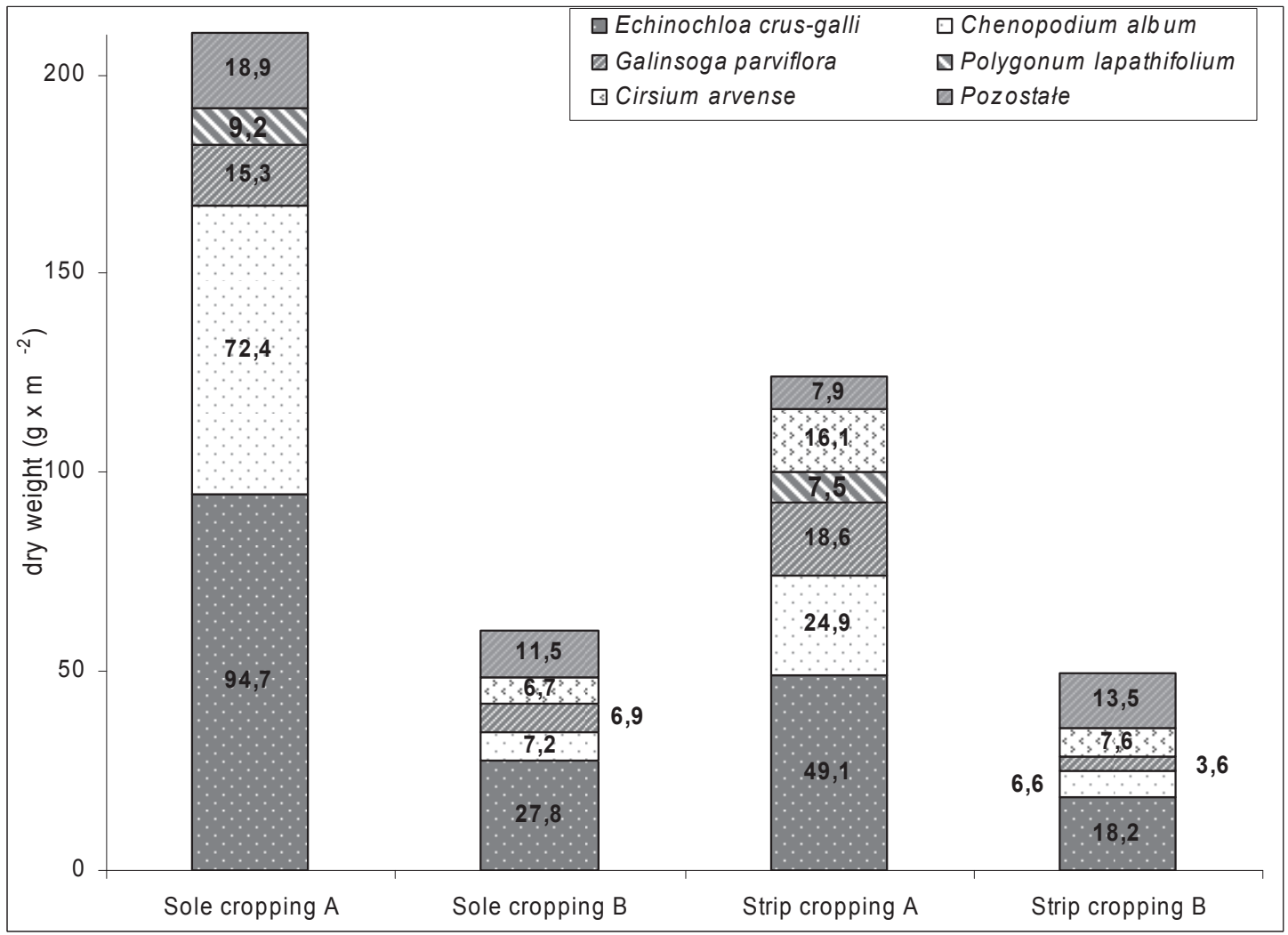

Fig. 1. Air-dry weight of aboveground parts of weed species in the maize crop (mean for 2008-2010). 


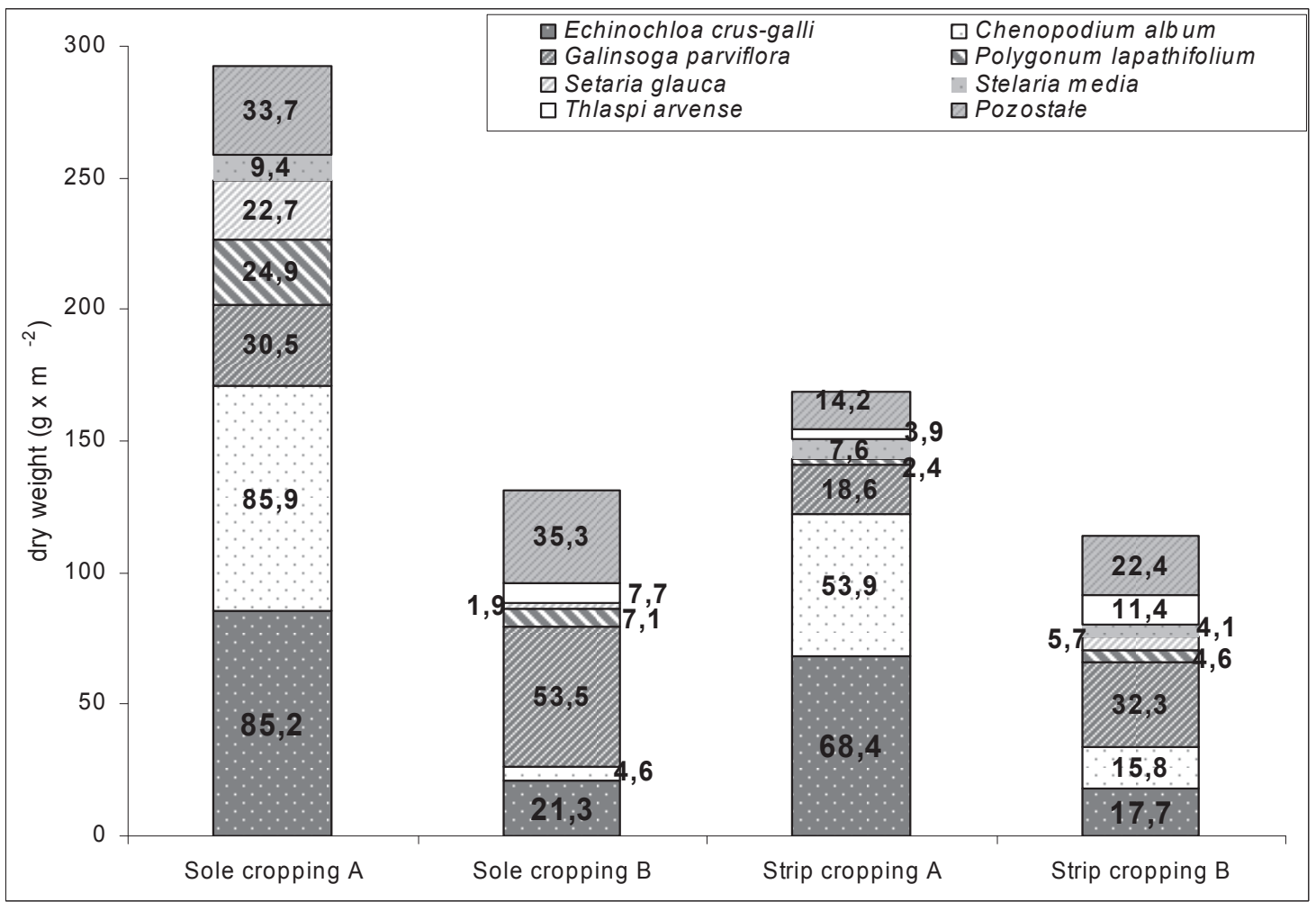

Fig. 2. Air-dry weight of aboveground parts of weed species in the common bean crop (mean for 2008-2010).

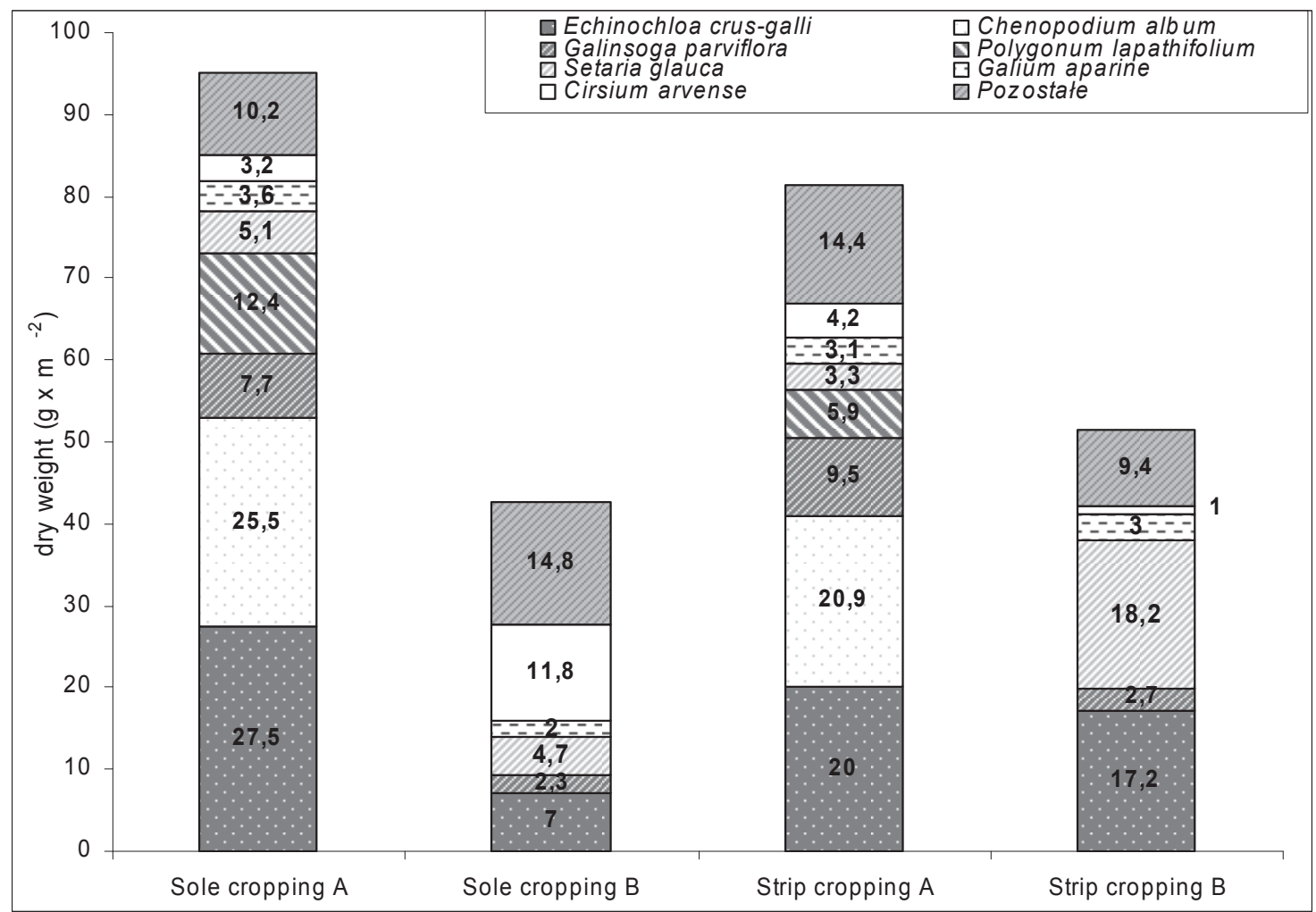

Fig. 3. Air-dry weight of aboveground parts of weed species in the spring barley crop (mean for 2008-2010). 


\section{DISCUSSION}

Irrespective of the factors examined, the dominant weeds in the crops of dent maize, common bean and spring barley were Echinochloa crus-galli, Chenopodium album and Galinsoga parviflora. Echinochloa crus-galli, a photosynthesis $\mathrm{C} 4$ plant belonging to the grass family, widespread throughout the world, is one of the most noxious weeds ( $\mathrm{R}$ a o et al. 2007; $\mathrm{C} \mathrm{h}$ a u han and Johnson, 2010). Gołębiowska (2006) as well as Sekutowski and Rola (2010) also report that Echinochloa crus-galli and Chenopodium album are dangerous weeds in crops, due to their frequency of occurrence and damage potential. The damage done by Echinochloa crus-galli depends not only on its density but also on the time of emergence. B o s n i c and Swant on (1997) reported that at a density of 200 plants per $1 \mathrm{~m}^{2}$ this species causes losses in yield of $26-35 \%$ when it emerges during the $1-2$-leaf stage of maize, but only a $6 \%$ loss if the maize has already produced at least 4 leaves. According to Głow acka (2011), in addition to the species mentioned above, Galinsoga parviflora also occurs frequently in maize. The dominant weed species in this study are mentioned by $\mathrm{Chmielowiec}$ and B o r ow y (2004) as well as G łow a c k a (2010) as the species most frequently occurring in common bean crops in south-eastern Poland. Galinsoga parviflora, which occurred frequently in the study, especially in the maize and beans crops, is currently a very common and rather troublesome weed in root crops, maize, and - less frequently - cereals. It is also often present in ruderal areas, usually in warm locations with abundant nutrients and neutral pH (W n u k and $\mathrm{Zi} \mathrm{a} \mathrm{j} \mathrm{a,} \mathrm{2010).}$

Leguminous plants grow slowly in the initial phase, creating favorable conditions for the development of weeds. Mechanical methods of weed control are not always effective, especially in unfavorable weather conditions. Bean plants are relatively small, which also increases their susceptibility to weed infestation, particularly in the initial period of growth $(\mathrm{He} \mathrm{k} \mathrm{m} \mathrm{a} \mathrm{t}$ et al. 2007). In this study, weed infestation of common bean at the sites where only mechanical weed control was used was significantly higher than in the case of the chemical methods. Chemical weed control reduced the number and dry weight of weeds and increased the diversity of segetal species in the bean crop, which is consistent with the results of other studies ( $\mathrm{G} \mathrm{ow} \mathrm{a} \mathrm{c} \mathrm{k} \mathrm{a,}$ 2010). While the use of herbicides did not significantly affect the number of Chenopodium album, the low dry weight produced by this taxon indicates that the weeds emerged later, when the herbicide was no longer active. The high number and dry weight of Galinsoga parviflo$r a$ were both due to secondary weed infestation of the beans, because it is a species that emerges at different times, grows very rapidly, flowers in the fourth week after germination, and can have 2 or 3 generations over the course of a year (W n u k and $\mathrm{Zi} \mathrm{a} \mathrm{j} \mathrm{a,2010).}$

The cultivation of maize in wide interrows favours the use of mechanical weed control ( $\mathrm{R}$ a f $\mathrm{f} \mathrm{a} \mathrm{e} 1 \mathrm{l} i$ et al. 2005). However, the mechanical method is often insufficiently effective because weeds in the maize rows are not completely destroyed (A b din et al. 2000). The present study also found that weed infestation of maize expressed as the number of weeds per unit area was significantly higher in the case of mechanical weed control. Moreover, the dry weight of weeds, which is a better indicator of noxious weed infestation, was three times higher in maize weeded mechanically. Echinochloa crus-galli, Chenopodium album and Galinsoga parviflora had the largest share of both the total number and biomass of weeds. These species are much more competitive than maize in terms of uptake of nutrients such as potassium, calcium and magnesium, and when they produce high biomass they may accumulate significant amounts of these macronutrients, thereby reducing their availability to maize ( $\mathrm{G} \mathrm{fow} \mathrm{a} \mathrm{c} \mathrm{k} \mathrm{a,} \mathrm{2011).}$ The number of species infesting the dent maize, by contrast, was not affected by the weed control method.

Mechanical weed control in cereals is limited to harrowing 1-3 times. The effectiveness of harrowing in destroying weeds depends on when it is done, the species composition of weeds, and their stage of development. In a study by W o ź n i a k (2004), the use of herbicides in barley reduced the number of weeds by $61 \%$ and their biomass by $45.6 \%$ in comparison to harrowing. Similar results were obtained in the present study. On average for the entire study, chemical weed control reduced the number of weeds by $64.4 \%$ and their biomass by $46.7 \%$ compared with the mechanical method (double harrowing). Chemical weed control completely eliminated Chenopodium album, a taxon regarded as one of major competitors for spring barley, from the weed community (Kostrzew ska and Wan i c, 2005).

Mixed cropping increases the genetic diversity of cultivated plants, thereby improving their health and production capacity (L e s z c z y ń s k a and C a c a k- Pi etrzak, 2006). Strip cropping, which is a form of mixed cropping, reduces the threat posed by pests, including weeds, so that pesticide use can be restricted (Carruthers et al. 1998). Li ebman and Dyck (1993) also suggest that weed infestation of crops can be reduced by the introduction of strip cropping. Studies conducted in Poland have determined that strip cropping of maize, common bean and spring wheat reduced both the number and dry weight of weeds in crops of common bean and spring wheat in comparison with sole cropping ( $\mathrm{G}$ o w a c k a, 2006; 2007). In the maize, however, the effect of strip cropping reduced the density of weeds, but their dry weight did not change significantly (G łow a cka, 2010). In the present 
experiment, strip cropping of dent maize with common bean and spring barley also significantly affected weed infestation of the crops compared with cultivation of these species in sole cropping. In the maize and common bean, strip cropping decreased both the number of weeds per unit area and the above-ground dry weight produced. In spring barley, however, a significant effect of strip cropping was found only for the density of weeds per unit area, while their weight did not change significantly. It is worth mentioning that the positive effect of strip cropping on weed infestation was especially apparent in combination with the mechanical weed control method. This indicates that this system could be useful in sustainable and organic agriculture ( $\mathrm{G}$ ło w a c k a , 2010). The differences observed in weed infestation between sole and strip cropping may result in part from the impact of strip cropping on the microclimate of the field. J urik and V an (2004) found significant changes in the intensity of photosynthetically active light, air and soil temperature, and humidity between the edge and the central part of the field.

\section{CONCLUSIONS}

1. In the experiment, a total of 36 taxa were recorded, of which 32 were ephemeral and 4 perennial. 22 species were found in the dent maize crops, in common bean 24 species, while the spring barley crops were characterized by the greatest diversity - 32 segetal taxa.

2. Irrespective of the crop plant, Echinochloa crus-galli, Chenopodium album and Galinsoga parviflo$r a$ were the most common taxa in the experiment. These species also produced the highest dry weight.

3 . Strip cropping significantly reduced both the number and dry weight of weeds in the dent maize and common bean crops compared to sole cropping. In the spring barley, the limiting effect of cropping method was significant only for the number of weeds.

4. As might be expected, the chemical method of weed control significantly reduced both the number and weight of weeds in all plants, in relation to the mechanical method.

5. The changes observed in the number and weight of weeds show that strip cropping reduces weed infestation of crops. Beneficial effects of strip cropping depend on the plant species, weed control methods, and meteorological conditions during the growing season.

\section{Acknowledgements}

This research was supported by the Ministry of Science and Higher Education of Poland as part of the statutory activities of the Faculty of Agricultural Sciences in Zamość

\section{REFERENCES}

Abdin O.A., Zhou X.M., Cloutier D., Coulman D.C., Faris M.A., Smith D.L. 2000. Cover crops and interrow tillage for weed control in short season maize (Zea mays). Eur. J. Agron. 12: 93-102. http://dx.doi.org/10.1016/S1161-0301(99)00049-0

Bosnic A.C., Swanton C.J. 1997. Influence of barnyardgrass (Echinochloa crus-galli) time of emergence and density on corn (Zea mays L.). Weed Sci. 45: 276-282.

B u r z y k P. 2003. Zalety upraw pasowych z wsiewką roślin motylkowatych a możliwość ograniczania strat azotu. / Advantages of strip intercropping system with legumes and possibilities to reduce nitrate losses. Post. Nauk Rol. 2: 16-21. (in Polish).

Carruthers K.Fe.Q., Cloutier D., Smith D.L. 1998. Intercropping corn with soybean, lupine and forages: weed control by intercropping combined with inter-row cultivation. Eur. J. Agron. 8: 225-238.

Chauhan B.S., John son D.E.2010. Implications of narrow crop row spacing and delayed Echinochloa colona and Echinochloa crus-galli emergence for weed growth and crop yield loss in aerobic rice. Field Crop Res. 117: 177-182. http://dx.doi.org/10.1016/j.fcr.2010.02.014

Chmielowiec P., Borowy A. 2004. Ocena działania bentazonu i metolachloru w uprawie fasoli zwykłej (Phaseolus vulgaris L.) 'BONA'. / Evaluation of the effect of bentazon and metolachlor in common bean (Phaseolus vulgaris L.) 'BONA' crops. Act. Sci. Pol., Hortorum Cultus 3(1): 75-87. (in Polish).

Ghaffarzadeh M., Garcia-Prechac F., Cruse R.M., Harbur M.M. 1998. Fertilizer and soil nitrogen use by corn and border crops in strip intercropping system. Agron. J. 90: 758-762. http://dx.doi.org/10.2134/agronj 1998.00021962009000060007x

Głowacka A. 2007. Wpływ współrzędnej uprawy pasowej na zachwaszczenie kukurydzy pastewnej. / The effect of strip intercropping system on weed infestation in maize. Acta Agrophys. 10(3): 573-582. (in Polish).

Głowacka A. 2008. Wpływ współrzędnej uprawy pasowej na wielkość i strukturę plonu kukurydzy pastewnej. I The effect of strip cropping on dimension and structure of maize field cultivated for silage. Fragm. Agron. 25(3): 52-60. (in Polish).

Głowacka A. 2010. Changes in weed infestation of common bean (Phaseolus vulgaris L.) under conditions of strip intercropping and different weed control methods. Acta Agrobot. 63 (2): 171-178.

Głowacka A. 2011. Dominant weeds in maize cultivation and their competitiveness under conditions of various methods of weed control. Acta Agrobot. 64 (2): 27-34.

Gołębiowska H. 2006. Wpływ wieloletniej uprawy kukurydzy na ziarno na występowanie chwastów. / Influence of grain maize monoculture on weed infestation Pam. Pul. 142: 127-136. (in Polish).

Hekmat S., Shropshire Ch., Soltani N., Sikkema P.H. 2007. Responses of dry beans (Phase- 
olus vulgaris L.) to sulfentrazone. Crop Protect. 26: 525-529.

Jurik T.W., Van K. 2004. Microenvironment of corn-soybean-oat strip intercrop system. Field Crop Res. 90: 335349. http://dx.doi.org/10.1016/j.cropro.2006.05.002

Kaczorowska T. 1962. Opady w Polsce w przekroju wieloletnim. / Rainfall in Poland in a long term. PAN, Inst. Geografii. Prace Geograf. 33: ss. 112. (in Polish).

Kostrzewska M.K., Wanic M. 2005. Zbiorowiska chwastów jęczmienia jarego w zależności od stanowiska w płodozmianie. / Communities of spring barley weeds depending on its place in the rotation system. Fragm. Agron. 2: 90-96. (in Polish).

Les oing G.W., Francis C.A. 1999. Strip intercropping effect on yield and yield components of corn, grain sorghum and soybean. Agron. J. 91: 807-813. http://dx.doi. org/10.2134/agronj1999.915807x

Leszczyńska D., Cacak-Pietrzak G. 2006. Wpływ obecności owsa (formy oplewionej i nieoplewionej) na cechy plonotwórcze jęczmienia w zasiewie mieszanym. / The effect of the presence of oat (hulled and naked form) on yielding parameters of barley in a mixed stand. Prog. Plant Protect./Post. Ochr. Roś. 46 (2): 19-23. (in Polish).

Liebman M., Dyck E. 1993. Crop rotation and intercropping for weed management. Ecol. App. 3: 92-122. http:// dx.doi.org/10.2307/1941795

Mirek Z., Piękoś-Mirkowa H., Zając A., Zając M. 2002. „Flowering plants and pterdophytes of Poland. A check list" Krytyczna lista roślin naczyniowych Polski. Wyd. Inst. Botaniki im. W. Szafera PAN Kraków.

Raffaelli M., Barberi P., Peruzzi A., Ginanni M. 2005. Mechanical weed control in maize: Evaluation of weed harrowing and hoening systems. Agricol. Medit. 135: 33-43.

Rao A.N., Johnson D.E., Sivaprasad B., Ladha J.K., Mortimer A.M. 2007. Weed management in direct-seeded rice. Adv. Agron. 93: 153-255.

Rogobete G., Grozav A. 2011. Methods for assessment of soil erosion. Res. J. Agric. Sci. 43: 174-179.

Sekutowski T., Rola H. 2010. Wpływ monokultury i systemu uprawy roli oraz ochrony herbicydowej na agrofitocenozę kukurydzy. / Determination of monoculture, tillage system and herbicide application on maize agrophytocenosis. Fragm. Agronom. 27(1): 128-140. (in Polish).

Smith R.J., Hanckok N.H., Ruffini J.L. 1991. Strip cropping - development of guidelines for the selection of strip spacing. Agric. Water Manag. 20: 1-16. http://dx.doi.org/10.1016/0378-3774(91)90031-D

Stuczyński T., Demidowicz G., Deputat T. Górski T., Krasowicz S., Kuś J. 2000. Adaptation scenarious of agriculture in Poland to future climate changes. Environ. Monitor. Assess. 61: 133-144.

Stupnicka-Rodzynkiewicz E., Lepiarczyk A. 2000. Wpływ zmianowania, sposobu uprawy roli i herbicydów na bioróżnorodność zbiorowisk chwastów. I
The effect of crop rotation, soil tillage and herbicides on the biodiversity of weeds. Acta Agr. et Silv. 34: 127-130. (in Polish).

Woźniak A. 2004. Następczy wpływ jęczmienia jarego uprawianego w zmianowaniu i monokulturze na zachwaszczenie pszenicy ozimej. / Residual effect of spring barley cultivated in crop rotation and in monoculture on weed infestation of winter wheat. Annales UMCS, sec. E, 3: 1029-1036. (in Polish).

Wnuk Z., Ziaja M.2010. Galinsoga sp.w zbiorowiskach segetalnych pasma przedborsko-małogoskiego. / $\mathrm{Ga}$ linsoga sp. in segetal communities of the Range Przedborsko-Małogoskie. Fragm. Agron. 27(3): 159-166. (in Polish).

Zhang F., Li L. 2003. Using competitive and facilitative interactions in intercropping systems enhances crop productivity and nutrient-use efficiency. Plant Soil, 248: 305-312. http://dx.doi.org/10.1023/A:1022352229863

\section{Wpływ uprawy pasowej na stan i stopień zachwaszczenia kukurydzy pastewnej (Zea mays L.) fasoli zwyczajnej (Phaseolus vulgaris $\mathbf{L}$.) i jęczmienia jarego (Hordeum vulgare $\mathrm{L}$.)}

\section{Streszczenie}

Doświadczenie przeprowadzono w latach 2008-2010 w Stacji Doświadczalnej Wydziału Nauk Rolniczych w Zamościu, Uniwersytetu Przyrodniczego w Lublinie. Schemat badań obejmował dwa czynniki: I. Metoda uprawy - siew czysty i uprawa pasowa, polegająca na uprawie w sąsiadujących ze sobą pasach o szerokości 3,3 m trzech roślin: kukurydzy pastewnej, fasoli zwyczajnej i jęczmienia jarego; II. Metody regulacji zachwaszczenia - mechaniczna i chemiczna Przedmiotem badań było zachwaszczenie kukurydzy pastewnej odmiany 'Celio', fasoli zwyczajnej odmiany 'Aura' i jęczmienia jarego odmiany 'Start'. Zachwaszczenie roślin określano dwa tygodnie przed zbiorem, metodą botaniczno-wagową, określając skład florystyczny i liczebność poszczególnych gatunków chwastów oraz ich powietrznie suchą masę.

Gatunkami dominującymi w zachwaszczeniu kukurydzy, fasoli zwyczajnej i jęczmienia jarego były Echinochloa crus-galli, Chenopodium album oraz Galinsoga parviflora stanowiące od 58\% do 70\% ogólnej liczby chwastów. Uprawa pasowa wyraźnie zmniejszała liczbę chwastów na jednostce powierzchni we wszystkich uprawianych gatunkach oraz wytworzoną przez nie sucha masę części nadziemnych w zasiewach fasoli zwyczajnej i kukurydzy pastewnej. Ograniczający wpływ uprawy pasowej na wskaźniki zachwaszczenia był szczególnie wyraźny w połączeniu $\mathrm{z}$ mechaniczną metodą regulacji zachwaszczenia. 